\title{
SISTEM PENDUKUNG KEPUTUSAN PENJURUSAN SISWA MENGGUNAKAN ALGORITMA SIMPLE ADDITIVE WEIGHTING
}

\author{
Sutrisno $^{1)}$, Yustina Retno Wahyu Utami ${ }^{2)}$, Andriani Kusumaningrum ${ }^{3)}$ \\ 1) 2) Program Studi Teknik Informatika \\ 3) Program Studi Komputerisasi Akuntansi \\ ${ }^{1)}$ stmastris@gmail.com, ${ }^{2)}$ yustina_retno@sinus.ac.id, ${ }^{3)}$ andrianikkw@ sinus.ac.id
}

\begin{abstract}
An inappropriate high school major can be detrimental to the students in the future. The right majors, are expected to maximize the students' potential, talent, and ability so that it will maximize their academic value either. The method of the major determination at school is basically still using conventional methods. So there are still some weaknesses occur. The determination process is based only on students' ranking without specifying the weight of each criteria. With the method based on analysis and experience that had happened, there are still some students cannot compete with his classmates in developing his academic potential. Ultimately to solve the problem in one school, it needs to re-clarify at the beginning of the even semester to map the ability of each student adn the necessity to build a students' major determination application based on the students' academic potential which is able to generate maximum decision from each student. By looking at the existing problems, it is necessary to make an alternative solution that is by designing and building Design Supporting System in Simple Additive Weighting (SAW) method, supported by Unified Modelling Language (UML) as application design, PHP as programming language and MySQL as its database. In the test of built application, using the Blackbox methods, and the system feasibility test result using 25 test attributes in which 21 are valid while the rest 4 are invalid and the feasibility value generated from the system of $84 \%$. Thus, the application is eligible to use despite the repair and development still needs to be improved.

Keywords: Decision Support System, High School Majors, Simple Additive Weighting.
\end{abstract}

\section{PENDAHULUAN}

Penjurusan yang tidak tepat dapat merugikan siswa dan karirnya di masa mendatang, dengan penjurusan yang tepat diharapkan dapat memaksimalkan potensi, bakat dan kemampuan dari individu tersebut, sehingga akan memaksimalkan nilai akademisnya. Penentuan jurusan ini akan berdampak terhadap kegiatan akademik selanjutnya dan mempengaruhi pemilihan bidang ilmu atau studi bagi siswa-siswi yang ingin melanjutkan ke perguruan tinggi nantinya (Nugroho \& Haryati, 2015). Beberapa permasalahan yang dihadapi dalam penjurusan siswa yang selama ini dilakukan oleh sebagian peneliti diantaranya adalah:

a. Metode Penjurusan yang dilakukan bersifat manual tanpa menerapkan suatu perhitungan yang lebih teliti terhadap kriteria yang diberikan.

b. Belum dibangunnya sebuah aplikasi penjurusan siswa yang mampu menghasilkan keputusan terbaik dari sebuah sistem.

Adapun nilai keuntungan dengan dibangunnya Sistem Pendukung Keputusan ini adalah sebagai berikut:

a. Peneliti menerapkan algoritma ilmiah yang telah teruji dalam menentukan sebuah keputusan, sehingga mampu menghasilkan penjurusan yang tepat sesuai dengan kriteria yang ditentukan.

b. Aplikasi yang dibangun oleh Peneliti berbasis website, dengan Graphic User Interface Friendly (GUI). 
Oleh karena itu, penelitian ini fokus pada bagaimana pengembangan sistem penjurusan siswa sehingga dapat memberikan alternatif keputusan baik bagi siswa ataupun pihak sekolah sesuai dengan kriteria minat, nilai mata pelajaran, dan nilai psikotes.

\section{TINJAUAN PUSTAKA}

Beberapa teori yang digunakan dalam proses penelitian diantaranya teori tentang sistem pendukung keputusan dan teori tentang Simple Additive Weighting.

Konsep dasar metode SAW adalah mencari penjumlahan terbobot dari rating kinerja pada setiap alternatif pada semua atribut. Metode Simple Additive Weighting membutuhkan proses normalisasi matriks keputusan (X) ke suatu skala yang dapat diperbandingkan dengan semua rating alternatif yang ada. Metode $S A W$ sering juga dikenal istilah metode penjumlahan terbobot. Konsep dasar metode SAW adalah mencari penjumlahan terbobot dari rating kinerja pada setiap alternatif pada semua atribut. Metode SAW membutuhkan proses normalisasi matriks keputusan (X) ke suatu skala yang dapat diperbandingkan dengan semua rating alternatif yang ada(Kusrini, 2010).

Formula untuk melalukan normalisasi tersebut adalah sebagai berikut:

$$
r_{i j}= \begin{cases}\frac{x_{i j}}{\operatorname{Max}_{i} x_{i j}} & \text { Jika } \mathrm{j} \text { adalah atribut keuntungan (benefit) } \\ \frac{{ }_{i}^{M i n} x_{i j}}{x_{i j}} & \text { Jika j adalah atribut biaya (cost) }\end{cases}
$$

Keterangan:

$\mathrm{r}_{\mathrm{ij}} \quad=$ nilai rating kinerja ternormalisasi

$\mathrm{x}_{\mathrm{ij}} \quad=$ nilai atribut yang dimiliki setiap kriteria

$\operatorname{Max} \mathrm{x}_{\mathrm{ij}}=$ nilai terbesar dari setiap kriteria

Min $\mathrm{x}_{\mathrm{ij}}=$ nilai terkecil dari setiap kriteria

Penjurusan merupakan salah satu proses penempatan atau penyaluran program pengajaran dalam lembaga pendidikan terutama SMA. Dalam penjurusan ini, siswa diberi kesempatan memilih jurusan yang paling cocok dengan karakteristik dirinya. Ketepatan memilih jurusan dapat menentukan keberhasilan belajar siswa. Tujuan penjurusan, antara lain mengelompokkan siswa sesuai dengan kecakapan, kemampuan, bakat, dan minat yang relatif sama. Membantu mempersiapkan siswa melanjutkan studi dan memilih dunia kerja. Membantu memperoleh keberhasilan dan kecocokan atau prestasi yang akan dicapai diwaktu mendatang, untuk melanjutkan studi atau dunia kerja. Penelitian mengenai penjurusan siswa SMA telah dilakukan dengan pohon keputusan (Kustiyahningsih \& Rahmanita, 2016). Dalam penelitian ini, algoritma C4.5 digunakan untuk menentukan jurusan IPA atau IPS. nilai Matematika, Fisika, Biologi, Kimia, Nilai Psikotest (IQ), Saran Psikotest, Angket/Minat Siswa, Saran Bimbingan Konseling.

Simple Additive Weighting(SAW) adalah metode terkenal yang diterapkan dalam lingkungan fuzzy(Yu, 2015). Penerapan pengambilan keputusan kuantitatif guna membandingkan bahan bakar fosil dengan energi nuklir untuk pembangkit tenaga listrik, dengan metode DEA dan SAW(Shakouri G., Nabaee, \& Aliakbarisani, 2014). Multi criteria decision menyediakan alat yang handal dalam masalah sorting. Teknik sederhana yang dapat digunakan untuk evaluasi antara lain metode SAW(Tamošaitienè, Zavadskas, \& Turskis, 2013). Dalam penilaian risiko dalam industri farmasi di Iran yang mempertimbangkan prioritas proses, bahaya dan probabilitas risiko, metode SAW digunakan untuk evaluasi resiko(Jaberidoost et al., 2015). Dalam penelitian lainnya, metode SAW juga diimplementasikan untuk menentukan desa penerima air bersih. Pada 
penelitian tersebut, penentuan desa penerima air bersih menggunakan 4 kriteria yaitu jumlah rumah, medan(kondisi jalan), jarak distribusi, dan penghasilan tiap desa di kecamatan Sumberlawang, Sragen (Sasongko, Tomo, \& Fitriasih, 2018).

\section{METODE PENELITIAN}

\subsection{Pengumpulan Data}

Dalam metode ini, Peneliti mengumpulkan berbagai data untuk mendukung sistem yang dibangun untuk hasil yang lebih baik. Adapun metode pengumpulan data yang dilakukan oleh Peneliti antara lain:

a. Observasi

Metode observasi mempunyai kelebihan yaitu peneliti mengetahui dengan jelas proses penjurusan yang dilakukan.

b. Wawancara

Proses wawancara yang dilakukan dengan mengajukan pertanyaan kepada Panitia Penerimaan Siswa Baru (PSB), yang terkait dengan proses penerimaan peserta didik baru.

c. Studi Pustaka

Peneliti mencari referensi dari berbagai sumber, baik Jurnal Ilmiah maupun buku-buku yang berkaitan dengan permasalahan yang diangkat.

\subsection{Pengolahan Data}

Data yang digunakan dalam penelitian ini diperoleh dari proses penjurusan pada Tahun Pelajaran 2016/2017 di SMA Negeri 2 Wonogiri. Terdapat 60 sampel data dengan atribut sebagai berikut:
a. Data Nomor Pendaftaran Siswa
b. Data Nama Siswa
c. Data Jurusan
d. Data Minat Siswa
e. Data Jumlah Nilai SHUN
f. Data Nilai Psikotest

\section{HASIL DAN PEMBAHASAN \\ 4.1 Analisis Sistem Yang Berjalan}

Sistem yang berjalan dalam melakukan proses penjurusan siswa menggunakan tahapan sebagai berikut:

a. Proses mengelola data siswa kelas Sepuluh

b. Proses menentukan kriteria penjurusan.

c. Proses melakukan klasifikasi atau memasukan data kriteria yang dimiliki oleh siswa kelas X (Sepuluh)

d. Proses perhitungan total poin yang dimiliki oleh setiap siswa.

Dan proses perhitungannya sebagai berikut:

$$
\begin{array}{ll}
\text { TP } & \multicolumn{2}{l}{\mathbf{N A}+\sum \mathbf{I Q}+\sum \mathbf{M J}} \\
\text { Keterangan: } & \\
\text { TP } & : \text { Total Poin } \\
\sum \mathrm{NA} & : \text { Total Penjumlahan Nilai SHUN } \\
\sum \mathrm{IQ} & : \text { Nilai Tes Psikologi } \\
\sum \mathrm{MJ} & : \text { Bobot Minat Jurusan }
\end{array}
$$


Komponen total nilai SHUN adalah:

* Nilai Mapel Bahasa Indonesia

* Nilai Mapel Bahasa Inggris

* Nilai Mapel Matematika

* Nilai Mapel IPA

Komponen total nilai Psikologi adalah:

* Komitmen bekerja

* Kreativitas

* Keyakinan diri

* Peka lingkungan

* Komunikasi Sosial

* Cara Kerja

* Tempramen

* Kepedulian Sesama

Komponen Minat atau Jurusan adalah:

* Saran Orang tua

* Keinginan pribadi

* Prospek Kerja

* Proses perangkingan

* Proses pengelompokan jurusan berdasarkan ranking.

\subsection{Analisis Sistem Yang Diusulkan}

Pada bagian ini dilakukan analisis sistem berdasarkan data dan informasi yang diperlukan dalam metode Simple Additive Weighting (SAW).

\section{a. Data Kriteria}

Pembobotan yang diberikan atas rekomendasi dari Panitia Penerimaan Siswa Baru (PSB) bidang Analisis. Bobot kriteria tersebut apabila dijumlahkan mempunyai nilai normalisasi atau bernilai satu. Adapun data kriteria dan sub kriteria ditunjukkan pada Tabel 1.

Tabel 1. Data Kriteria

\begin{tabular}{|c|c|c|c|c|}
\hline No & Nama Kriteria & Cost / Benefit & Bobot Nilai & Prosentase \\
\hline 1 & Jumlah Nilai SHUN & Benefit & 0,5 & $50 \%$ \\
\hline 2 & Nilai Psikotest & Benefit & 0,3 & $30 \%$ \\
\hline 3 & Minat Jurusan & Benefit & 0,2 & $20 \%$ \\
\hline
\end{tabular}

Tabel 2. Kriteria Minat

\begin{tabular}{|c|c|c|}
\hline No & Minat & Nilai \\
\hline 1 & IPA & 0.5 \\
\hline 2 & IPS & 0.3 \\
\hline 3 & BAHASA & 0.2 \\
\hline
\end{tabular}

Tabel 3. Kriteria Jumlah Nilai UN

\begin{tabular}{|c|c|c|}
\hline No & Range Nilai UN & Nilai \\
\hline 1 & $<270$ & 0.001 \\
\hline 2 & $271-273$ & 0.002 \\
\hline 3 & $274-276$ & 0.003 \\
\hline 4 & $277-280$ & 0.004 \\
\hline 5 & $281-283$ & 0.01 \\
\hline 6 & $284-286$ & 0.015 \\
\hline 7 & $287-290$ & 0.02 \\
\hline
\end{tabular}




\begin{tabular}{|c|c|c|}
\hline No & Range Nilai UN & Nilai \\
\hline 8 & $291-293$ & 0.025 \\
\hline 9 & $294-296$ & 0.03 \\
\hline 10 & $297-300$ & 0.35 \\
\hline 11 & $301-303$ & 0.04 \\
\hline 12 & $304-306$ & 0.045 \\
\hline 13 & $307-310$ & 0.05 \\
\hline 14 & $311-313$ & 0.055 \\
\hline 15 & $314-316$ & 0.06 \\
\hline 16 & $317-320$ & 0.065 \\
\hline 17 & $321-323$ & 0.09 \\
\hline 18 & $324-326$ & 0.1 \\
\hline 19 & $326-330$ & 0.15 \\
\hline 20 & $>331$ & 0.2 \\
\hline
\end{tabular}

Tabel. 4. Kriteria Nilai Psikotest

\begin{tabular}{|c|c|c|}
\hline No. & Range Nilai & Nilai \\
\hline 1 & $<80$ & 0.025 \\
\hline 2 & $81-85$ & 0.03 \\
\hline 3 & $86-90$ & 0.035 \\
\hline 4 & $91-95$ & 0.04 \\
\hline 5 & $96-100$ & 0.045 \\
\hline 6 & $101-105$ & 0.05 \\
\hline 7 & $106-110$ & 0.055 \\
\hline 8 & $111-115$ & 0.06 \\
\hline 9 & $116-120$ & 0.065 \\
\hline 10 & $121-125$ & 0.9 \\
\hline 11 & $126-130$ & 0.1 \\
\hline 12 & $>131$ & 0.405 \\
\hline
\end{tabular}

\section{b. Klasifikasi}

Data nilai kriteria setiap calon siswa yang digunakan, ditunjukkan pada Tabel 5.

Tabel 5. Data Calon Siswa

\begin{tabular}{|c|c|l|c|c|c|c|}
\hline NO & $\begin{array}{c}\text { NO } \\
\text { PENDAFTAR }\end{array}$ & NAMA SISWA BARU & $\begin{array}{c}\text { JUMLAH } \\
\text { NILAI }\end{array}$ & PSIKOTES & PILIHAN & BOBOT \\
\hline 1 & P.083 & Agustina Hastini & 316.0 & 97 & MIPA & 50 \\
\hline 2 & P.167 & Agustira Fatima A & 273.0 & 92 & IPS & 30 \\
\hline 3 & L.009 & Andreas Ani Asmara & 310.0 & 86 & BB & 20 \\
\hline 4 & P.005 & Anggita Yuniarti & 297.0 & 83 & IPS & 30 \\
\hline 5 & P.025 & Anggun Prasasti & 311.0 & 97 & BB & 20 \\
\hline 6 & P.185 & Atik Iis Oktaviasari & 293.5 & 109 & IPS & 30 \\
\hline 7 & P.176 & Ayu Fitria Nurjanah & 325.0 & 91 & BB & 20 \\
\hline 8 & P.203 & Cornelia Ayu H & 272.0 & 158 & BB & 20 \\
\hline 9 & L.080 & Daffa Rahardian & 314.5 & 92 & MIPA & 50 \\
\hline 10 & P.118 & Dina Agustin & 296.5 & 89 & BB & 20 \\
\hline 11 & P.123 & Fernanda Febrina S & 311.0 & 133 & BB & 20 \\
\hline 12 & P.179 & Julita Nur Cholifah & 275.5 & 122 & IPS & 30 \\
\hline 13 & L.034 & Kurnia Maulana P & 304.5 & 122 & IPS & 30 \\
\hline 14 & L.055 & Muhammad Alfian W & 280.0 & 145 & IPS & 30 \\
\hline 15 & P.151 & Nandila Astika N & 288.0 & 92 & BB & 20 \\
\hline 16 & P.360 & Nua Lani Anggraini & 278.5 & 113 & BB & 20 \\
\hline 17 & P.065 & Ratry Yogi R & 298.5 & 102 & IPS & 30 \\
\hline 18 & P.037 & Wahyu Pramesti & 275.5 & 109 & IPS & 30 \\
\hline 19 & P.352 & Widyani Sekar R & 285.5 & 99 & BB & 20 \\
\hline
\end{tabular}




\begin{tabular}{|c|c|c|c|c|c|c|}
\hline NO & $\begin{array}{c}\text { NO } \\
\text { PENDAFTAR } \\
\end{array}$ & NAMA SISWA BARU & $\begin{array}{c}\text { JUMLAH } \\
\text { NILAI }\end{array}$ & PSIKOTES & PILIHAN & BOBOT \\
\hline 20 & P.091 & Yolanda Diva R & 276.0 & 89 & IPS & 30 \\
\hline 21 & P.038 & Alicia Syafa Azizah & 292.5 & 73 & IPS & 30 \\
\hline 22 & P.134 & Anggita Ayu K & 291.0 & 96 & IPS & 30 \\
\hline 23 & P.326 & Anissa Ayu Puspita & 290.5 & 97 & MIPA & 50 \\
\hline 24 & L.190 & Arif Indarmawan & 324.0 & 92 & MIPA & 50 \\
\hline 25 & P.337 & Ariska Harnowo P & 315.5 & 118 & MIPA & 50 \\
\hline 26 & L.060 & Arvian Rendy P & 304.0 & 133 & IPS & 30 \\
\hline 27 & L.176 & Aryarestra Ravida A & 295.5 & 113 & IPS & 30 \\
\hline 28 & L.174 & Axel Gandy A & 292.5 & 105 & MIPA & 50 \\
\hline 29 & L.181 & Daffa Nur Rafie A & 311.5 & 127 & IPS & 30 \\
\hline 30 & L. 145 & Daffa Putra N & 312.5 & 118 & MIPA & 50 \\
\hline 31 & L.005 & David Septianus A & 314.5 & 113 & MIPA & 50 \\
\hline 32 & P.207 & Dearista R & 300.0 & 109 & MIPA & 50 \\
\hline 33 & P.063 & Dewanti Wahyu P & 307.0 & 102 & IPS & 30 \\
\hline 34 & L.089 & Dhimas Haryo Yudho & 311.0 & 133 & IPS & 30 \\
\hline 35 & L.027 & Dicky Kurniawan & 318.5 & 139 & MIPA & 50 \\
\hline 36 & P.035 & Diyah Ayu Pebrianti & 309.5 & 127 & MIPA & 50 \\
\hline 37 & P.204 & Evita Damayanti P & 293.5 & 99 & MIPA & 50 \\
\hline 38 & L.189 & Farkhan Surya Adi K & 312.0 & 94 & MIPA & 50 \\
\hline 39 & L.031 & Gallang Satria M & 322.5 & 133 & IPS & 30 \\
\hline 40 & P.208 & Gospel E & 276.5 & 96 & MIPA & 50 \\
\hline 41 & P.106 & Hanifah Febriyanti & 311.5 & 91 & MIPA & 50 \\
\hline 42 & P.028 & Hesfa Putri January & 316.5 & 109 & MIPA & 50 \\
\hline 43 & P.006 & Intan Fadhila & 308.5 & 97 & MIPA & 50 \\
\hline 44 & P.047 & Karista Yonika Putri & 307.5 & 102 & MIPA & 50 \\
\hline 45 & L. 153 & Mahendra Yudha P & 311.5 & 118 & MIPA & 50 \\
\hline 46 & P.327 & Marshella Sari N P & 307.5 & 105 & MIPA & 50 \\
\hline 47 & P.261 & Melladhiva Juand J & 312.0 & 89 & MIPA & 50 \\
\hline 48 & L.061 & Muhammad Y M & 299.5 & 109 & MIPA & 50 \\
\hline 49 & P.019 & Nanda Apriliasari & 311.0 & 96 & IPS & 30 \\
\hline 50 & P.161 & Pramita Widyadari & 281.0 & 105 & MIPA & 50 \\
\hline 51 & P.291 & R0ssita K & 305.0 & 113 & MIPA & 50 \\
\hline 52 & L.046 & Rakyan Yogaswara & 289.0 & 99 & MIPA & 50 \\
\hline 53 & L.162 & Rivaldo Pranandito & 293.0 & 96 & MIPA & 50 \\
\hline 54 & P.103 & Rizki Ramadhani & 313.0 & 113 & IPS & 30 \\
\hline 55 & L.057 & Saptian Azel Adyuta U & 309.0 & 94 & IPS & 30 \\
\hline 56 & P.256 & Sulfita Aurora Zahra & 318.0 & 91 & MIPA & 50 \\
\hline 57 & L.198 & Wali Mahendra G & 322.5 & 109 & IPS & 30 \\
\hline 58 & P.336 & Yohana Yasinta S & 302.0 & 97 & MIPA & 50 \\
\hline 59 & L.196 & Yosafat Putra P & 286.0 & 96 & MIPA & 50 \\
\hline 60 & P.104 & Zahra Oktavia S & 298.0 & 113 & MIPA & 50 \\
\hline
\end{tabular}

\section{c. Nilai Kriteria}

Proses perhitungan selanjutnya yaitu memberikan nilai pada masing-masing kolom, adapun acuan dalam memberikan nilai kriteria tersebut mengacu pada Tabel 2, Tabel 3, Tabel 4. Adapun hasil nilai dari setiap kriteria ditunjukkan pada Tabel. 6.

Tabel 6. Transformasi Data Diskritasi

\begin{tabular}{|l|l|l|c|c|c|}
\hline NO & $\begin{array}{l}\text { NO PENDAF- } \\
\text { TARAN }\end{array}$ & NAMA SISWA BARU & $\begin{array}{c}\text { JUMLAH } \\
\text { NILAI }\end{array}$ & $\begin{array}{c}\text { PSIKO } \\
\text { TES }\end{array}$ & PILIHAN \\
\hline 1 & P.083 & Agustina Hastini & 0.06000 & 0.04500 & 0.50000 \\
\hline 2 & P.167 & Agustira Fatima Azzahra & 0.00200 & 0.04000 & 0.30000 \\
\hline 3 & P.038 & Alicia Syafa Azizah & 0.02500 & 0.02500 & 0.30000 \\
\hline 4 & L.009 & Andreas Ani Asmara & 0.05000 & 0.03500 & 0.20000 \\
\hline
\end{tabular}




\begin{tabular}{|c|c|c|c|c|c|}
\hline NO & $\begin{array}{l}\text { NO PENDAF- } \\
\text { TARAN }\end{array}$ & NAMA SISWA BARU & $\begin{array}{c}\text { JUMLAH } \\
\text { NILAI }\end{array}$ & $\begin{array}{c}\text { PSIKO } \\
\text { TES }\end{array}$ & PILIHAN \\
\hline 5 & P.134 & Anggita Ayu Kurniasih & 0.02500 & 0.04500 & 0.30000 \\
\hline 6 & P.005 & Anggita Yuniarti & 0.03500 & 0.03000 & 0.30000 \\
\hline 7 & P.025 & Anggun Prasasti & 0.05500 & 0.04500 & 0.20000 \\
\hline 8 & P.326 & Anissa Ayu Puspita & 0.02000 & 0.04500 & 0.50000 \\
\hline 9 & L.190 & Arif Indarmawan & 0.10000 & 0.04000 & 0.50000 \\
\hline 10 & P.337 & Ariska Harnowo Putri & 0.06000 & 0.06500 & 0.50000 \\
\hline 11 & L.060 & Arvian Rendy Pernanda & 0.04500 & 0.40500 & 0.30000 \\
\hline 12 & L.176 & Aryarestra Ravida A R & 0.03000 & 0.06000 & 0.30000 \\
\hline 13 & P.185 & Atik Iis Oktaviasari & 0.02500 & 0.05500 & 0.30000 \\
\hline 14 & L.174 & Axel Gandy Arthayuda & 0.03000 & 0.05000 & 0.50000 \\
\hline 15 & P.176 & Ayu Fitria Nurjanah & 0.10000 & 0.04000 & 0.20000 \\
\hline 16 & P.203 & Cornelia Ayu Hafsari & 0.00200 & 0.40500 & 0.20000 \\
\hline 17 & L.181 & Daffa Nur Rafie Alam & 0.05500 & 0.10000 & 0.30000 \\
\hline 18 & L.145 & Daffa Putra Nugraha & 0.05500 & 0.06500 & 0.50000 \\
\hline 19 & L.080 & Daffa Rahardian & 0.06000 & 0.04000 & 0.50000 \\
\hline 20 & L.005 & David Septianus Agustia & 0.06000 & 0.05500 & 0.50000 \\
\hline 21 & P.207 & Dearista Rahmadhani & 0.03500 & 0.05500 & 0.50000 \\
\hline 22 & P.063 & Dewanti Wahyu P & 0.05000 & 0.05000 & 0.30000 \\
\hline 23 & L.089 & Dhimas Haryo Yudho & 0.05500 & 0.40500 & 0.30000 \\
\hline 24 & L.027 & Dicky Kurniawan & 0.06500 & 0.40500 & 0.50000 \\
\hline 25 & P.118 & Dina Agustin & 0.03000 & 0.03500 & 0.20000 \\
\hline 26 & P.035 & Diyah Ayu Pebrianti & 0.05000 & 0.10000 & 0.50000 \\
\hline 27 & P.204 & Evita Damayanti Puteri & 0.02500 & 0.04500 & 0.50000 \\
\hline 28 & L.189 & Farkhan Surya Adi Kirana & 0.05500 & 0.04000 & 0.50000 \\
\hline 29 & P.123 & Fernanda Febrina Shenny & 0.05500 & 0.40500 & 0.20000 \\
\hline 30 & L.031 & Gallang Satria Mujito & 0.09000 & 0.40500 & 0.30000 \\
\hline 31 & P.208 & Gospel Enggaringtyas & 0.00300 & 0.04500 & 0.50000 \\
\hline 32 & P.106 & Hanifah Febriyanti & 0.05500 & 0.04000 & 0.50000 \\
\hline 33 & P.028 & Hesfa Putri January & 0.06000 & 0.05500 & 0.50000 \\
\hline 34 & P.006 & Intan Fadhila & 0.05000 & 0.04500 & 0.50000 \\
\hline 35 & P.179 & Julita Nur Cholifah & 0.00300 & 0.09000 & 0.30000 \\
\hline 36 & P.047 & Karista Yonika Putri & 0.05000 & 0.05000 & 0.50000 \\
\hline 37 & L.034 & Kurnia Maulana Putra & 0.04500 & 0.09000 & 0.30000 \\
\hline 38 & L.153 & Mahendra Yudha Pradana & 0.05500 & 0.06500 & 0.50000 \\
\hline 39 & P.327 & Marshella Sari Novita Putri & 0.05000 & 0.05000 & 0.50000 \\
\hline 40 & P.261 & Melladhiva Juand Juliara & 0.05500 & 0.03500 & 0.50000 \\
\hline 41 & L.055 & Muhammad Alfian Wibisono & 0.00400 & 0.40500 & 0.30000 \\
\hline 42 & L.061 & Muhammad Yusyfarijal M & 0.03500 & 0.05500 & 0.50000 \\
\hline 43 & P.019 & Nanda Apriliasari & 0.05500 & 0.04500 & 0.30000 \\
\hline 44 & P.151 & Nandila Astika Ningrum & 0.02000 & 0.04000 & 0.20000 \\
\hline 45 & P.360 & Nua Lani Anggraini & 0.00400 & 0.06000 & 0.20000 \\
\hline 46 & P.161 & Pramita Widyadari & 0.01000 & 0.05000 & 0.50000 \\
\hline 47 & P.291 & R0ssita Kusumaningrum & 0.04500 & 0.06000 & 0.50000 \\
\hline 48 & L.046 & Rakyan Yogaswara & 0.02000 & 0.04500 & 0.50000 \\
\hline 49 & P.065 & Ratry Yogi Rahmawati & 0.03000 & 0.05000 & 0.30000 \\
\hline 50 & L. 162 & Rivaldo Pranandito & 0.02500 & 0.04500 & 0.50000 \\
\hline 51 & P.103 & Rizki Ramadhani & 0.05500 & 0.06000 & 0.30000 \\
\hline 52 & L.057 & Saptian Azel Adyuta Utama & 0.05000 & 0.04000 & 0.30000 \\
\hline 53 & P.256 & Sulfita Aurora Zahra & 0.06500 & 0.04000 & 0.50000 \\
\hline 54 & P.037 & Wahyu Pramesti & 0.00300 & 0.05500 & 0.30000 \\
\hline 55 & L.198 & Wali Mahendra Gandhi & 0.09000 & 0.05500 & 0.30000 \\
\hline 56 & P.352 & Widyani Sekar Ramadhania & 0.01500 & 0.04500 & 0.20000 \\
\hline 57 & P.336 & Yohana Yasinta Sidabutar & 0.04000 & 0.04500 & 0.50000 \\
\hline
\end{tabular}




\begin{tabular}{|l|l|l|c|c|c|}
\hline NO & $\begin{array}{l}\text { NO PENDAF- } \\
\text { TARAN }\end{array}$ & NAMA SISWA BARU & $\begin{array}{c}\text { JUMLAH } \\
\text { NILAI }\end{array}$ & $\begin{array}{c}\text { PSIKO } \\
\text { TES }\end{array}$ & PILIHAN \\
\hline 58 & P.091 & Yolanda Diva Rusdyana & 0.00300 & 0.04500 & 0.30000 \\
\hline 59 & L.196 & Yosafat Putra Pamungkas & 0.01500 & 0.04500 & 0.50000 \\
\hline 60 & P.104 & Zahra Oktavia Syahrani & 0.03500 & 0.06000 & 0.50000 \\
\hline
\end{tabular}

\section{d. Membuat Normalisasi}

Tahapan-tahapan selanjutnya dalam proses perhitungan algoritma SAW ini adalah dengan melakukan normalisasi dan proses normalisasi tersebut merujuk pada rumus (1) dan perhitungannya sebagai berikut:

\section{Normalisasi Pada Siswa Dengan Nomor Pendaftaran P.083}

Karena pada kasus ini bertipe Benefit, maka nilai pembaginya adalah nilai yang terbesar yang terdapat pada masing-masing kolom pada Tabel 6. Adapun perhitungan normalisasinya sebagai berikut:

Pada Kriteria Jumlah Nilai

$$
\text { rP.083.C1 }=0.06 / 0.1
$$

$$
=0.60
$$

Pada Kriteria Psikotes

$$
\begin{aligned}
\text { rP.083.C2 } & =0.045 / 0.405 \\
& =0,111
\end{aligned}
$$

$>$ Pada Kriteria Pilihan

$$
\begin{aligned}
\text { rP.083.C3 } & =0.5 / 0.5 \\
& =1,000
\end{aligned}
$$

Dengan menggunakan langkah yang sama pada perhitungan diatas, hasil normalisasi ditunjukkan pada Tabel 7.

Tabel 7. Tabel Hasil Normalisasi

\begin{tabular}{|c|c|l|c|c|c|}
\hline NO & $\begin{array}{c}\text { NO } \\
\text { PENDAFTARAN }\end{array}$ & NAMA SISWA BARU & $\begin{array}{c}\text { JUMLAH } \\
\text { NILAI }\end{array}$ & $\begin{array}{c}\text { PSIKOT } \\
\text { ES }\end{array}$ & PILIHAN \\
\hline 1 & P.083 & Agustina Hastini & 0.6000 & 0.1111 & 1.0000 \\
\hline 2 & P.167 & Agustira Fatima Azzahra & 0.0200 & 0.0988 & 0.6000 \\
\hline 3 & P.038 & Alicia Syafa Azizah & 0.2500 & 0.0617 & 0.6000 \\
\hline 4 & L.009 & Andreas Ani Asmara & 0.5000 & 0.0864 & 0.4000 \\
\hline 5 & P.134 & Anggita Ayu Kurniasih & 0.2500 & 0.1111 & 0.6000 \\
\hline 6 & P.005 & Anggita Yuniarti & 0.3500 & 0.0741 & 0.6000 \\
\hline 7 & P.025 & Anggun Prasasti & 0.5500 & 0.1111 & 0.4000 \\
\hline 8 & P.326 & Anissa Ayu Puspita & 0.2000 & 0.1111 & 1.0000 \\
\hline 9 & L.190 & Arif Indarmawan & 1.0000 & 0.0988 & 1.0000 \\
\hline 10 & P.337 & Ariska Harnowo Putri & 0.6000 & 0.1605 & 1.0000 \\
\hline 11 & L.060 & Arvian Rendy Pernanda & 0.4500 & 1.0000 & 0.6000 \\
\hline 12 & L.176 & Aryarestra Ravida A R & 0.3000 & 0.1481 & 0.6000 \\
\hline 13 & P.185 & Atik Iis Oktaviasari & 0.2500 & 0.1358 & 0.6000 \\
\hline 14 & L.174 & Axel Gandy Arthayuda & 0.3000 & 0.1235 & 1.0000 \\
\hline 15 & P.176 & Ayu Fitria Nurjanah & 1.0000 & 0.0988 & 0.4000 \\
\hline 16 & P.203 & Cornelia Ayu Hafsari & 0.0200 & 1.0000 & 0.4000 \\
\hline 17 & L.181 & Daffa Nur Rafie Alam & 0.5500 & 0.2469 & 0.6000 \\
\hline 18 & L.145 & Daffa Putra Nugraha & 0.5500 & 0.1605 & 1.0000 \\
\hline 19 & L.080 & Daffa Rahardian & 0.6000 & 0.0988 & 1.0000 \\
\hline 20 & L.005 & David Septianus Agustia & 0.6000 & 0.1358 & 1.0000 \\
\hline 21 & P.207 & Dearista Rahmadhani & 0.3500 & 0.1358 & 1.0000 \\
\hline 22 & P.063 & Dewanti Wahyu P & 0.5000 & 0.1235 & 0.6000 \\
\hline
\end{tabular}




\begin{tabular}{|c|c|c|c|c|c|}
\hline NO & $\begin{array}{c}\text { NO } \\
\text { PENDAFTARAN }\end{array}$ & NAMA SISWA BARU & $\begin{array}{c}\text { JUMLAH } \\
\text { NILAI }\end{array}$ & $\begin{array}{l}\text { PSIKOT } \\
\text { ES }\end{array}$ & PILIHAN \\
\hline 23 & L.089 & Dhimas Haryo Yudho & 0.5500 & 1.0000 & 0.6000 \\
\hline 24 & L.027 & Dicky Kurniawan & 0.6500 & 1.0000 & 1.0000 \\
\hline 25 & P.118 & Dina Agustin & 0.3000 & 0.0864 & 0.4000 \\
\hline 26 & P.035 & Diyah Ayu Pebrianti & 0.5000 & 0.2469 & 1.0000 \\
\hline 27 & P.204 & Evita Damayanti Puteri & 0.2500 & 0.1111 & 1.0000 \\
\hline 28 & L.189 & Farkhan Surya Adi Kirana & 0.5500 & 0.0988 & 1.0000 \\
\hline 29 & P.123 & Fernanda Febrina Shenny & 0.5500 & 1.0000 & 0.4000 \\
\hline 30 & L.031 & Gallang Satria Mujito & 0.9000 & 1.0000 & 0.6000 \\
\hline 31 & P.208 & Gospel Enggaringtyas & 0.0300 & 0.1111 & 1.0000 \\
\hline 32 & P.106 & Hanifah Febriyanti & 0.5500 & 0.0988 & 1.0000 \\
\hline 33 & P.028 & Hesfa Putri January & 0.6000 & 0.1358 & 1.0000 \\
\hline 34 & P.006 & Intan Fadhila & 0.5000 & 0.1111 & 1.0000 \\
\hline 35 & P.179 & Julita Nur Cholifah & 0.0300 & 0.2222 & 0.6000 \\
\hline 36 & P.047 & Karista Yonika Putri & 0.5000 & 0.1235 & 1.0000 \\
\hline 37 & L.034 & Kurnia Maulana Putra & 0.4500 & 0.2222 & 0.6000 \\
\hline 38 & L. 153 & Mahendra Yudha Pradana & 0.5500 & 0.1605 & 1.0000 \\
\hline 39 & P.327 & Marshella Sari Novita P & 0.5000 & 0.1235 & 1.0000 \\
\hline 40 & P.261 & Melladhiva Juand Juliara & 0.5500 & 0.0864 & 1.0000 \\
\hline 41 & L.055 & Muhammad Alfian W & 0.0400 & 1.0000 & 0.6000 \\
\hline 42 & L.061 & Muhammad Yusyfarijal M & 0.3500 & 0.1358 & 1.0000 \\
\hline 43 & P.019 & Nanda Apriliasari & 0.5500 & 0.1111 & 0.6000 \\
\hline 44 & P.151 & Nandila Astika Ningrum & 0.2000 & 0.0988 & 0.4000 \\
\hline 45 & P.360 & Nua Lani Anggraini & 0.0400 & 0.1481 & 0.4000 \\
\hline 46 & P.161 & Pramita Widyadari & 0.1000 & 0.1235 & 1.0000 \\
\hline 47 & P.291 & R0ssita Kusumaningrum & 0.4500 & 0.1481 & 1.0000 \\
\hline 48 & L.046 & Rakyan Yogaswara & 0.2000 & 0.1111 & 1.0000 \\
\hline 49 & P.065 & Ratry Yogi Rahmawati & 0.3000 & 0.1235 & 0.6000 \\
\hline 50 & L. 162 & Rivaldo Pranandito & 0.2500 & 0.1111 & 1.0000 \\
\hline 51 & P.103 & Rizki Ramadhani & 0.5500 & 0.1481 & 0.6000 \\
\hline 52 & L.057 & Saptian Azel Adyuta U & 0.5000 & 0.0988 & 0.6000 \\
\hline 53 & P.256 & Sulfita Aurora Zahra & 0.6500 & 0.0988 & 1.0000 \\
\hline 54 & P.037 & Wahyu Pramesti & 0.0300 & 0.1358 & 0.6000 \\
\hline 55 & L.198 & Wali Mahendra Gandhi & 0.9000 & 0.1358 & 0.6000 \\
\hline 56 & P.352 & Widyani Sekar R & 0.1500 & 0.1111 & 0.4000 \\
\hline 57 & P.336 & Yohana Yasinta Sidabutar & 0.4000 & 0.1111 & 1.0000 \\
\hline 58 & P.091 & Yolanda Diva Rusdyana & 0.0300 & 0.1111 & 0.6000 \\
\hline 59 & L.196 & Yosafat Putra Pamungkas & 0.1500 & 0.1111 & 1.0000 \\
\hline 60 & P.104 & Zahra Oktavia Syahrani & 0.3500 & 0.1481 & 1.0000 \\
\hline
\end{tabular}

\section{e. Penskoran Nilai}

Penskoran nilai diperoleh dari hasil perkalian bobot dengan setiap kriteria, sedangkan bobot pada kriteria tersebut sebagai berikut:

Jumlah Nilai 0,5

$>$ Nilai Psikotest 0,3

$>$ Pilihan Jurusan 0,2

Adapun perhitungan pada nomor pendaftaran P.083 adalah: 
Kriteria Jumlah Nilai

w.rP.083.C1 $=0.6 \times 0,5=0,3000$

Kriteria Psikotes

$$
\text { w.rP.083.C2 }=0,111111 \times 0,3=0,033333
$$

Pada Kriteria Pilihan

\section{w.rP.083.C3 $=0,200 \times 0,2=0,200$}

Total point yang dimiliki oleh P.083 adalah dengan menjumlahkan ketiga bobot pada semua kriteria yang dimilikinya yaitu:

Point Nilai P.083

$\Sigma \mathrm{w} . \mathrm{P} .083=0,3000+0,033333+0,2000=0.5333$

Hasil pembobotan dan penjumlahan pada 60 sampel data ditunjukkan pada Tabel 8.

Tabel 8. Tabel Penjumlahan Pembobotan

\begin{tabular}{|c|c|c|c|c|c|c|}
\hline NO & $\begin{array}{c}\text { NO } \\
\text { PENDAFT. }\end{array}$ & NAMA SISWA BARU & $\begin{array}{c}\text { JUMLAH } \\
\text { NILAI }\end{array}$ & PSIKOTES & PILIHAN & $\Sigma$ Total Poin \\
\hline 1 & P.083 & Agustina Hastini & 0.3000 & 0.0333 & 0.2000 & 0.5333 \\
\hline 2 & P.167 & Agustira Fatima A & 0.0100 & 0.0296 & 0.1200 & 0.1596 \\
\hline 3 & P.038 & Alicia Syafa Azizah & 0.1250 & 0.0185 & 0.1200 & 0.2635 \\
\hline 4 & L.009 & Andreas Ani Asmara & 0.2500 & 0.0259 & 0.0800 & 0.3559 \\
\hline 5 & P.134 & Anggita Ayu Kurniasih & 0.1250 & 0.0333 & 0.1200 & 0.2783 \\
\hline 6 & P.005 & Anggita Yuniarti & 0.1750 & 0.0222 & 0.1200 & 0.3172 \\
\hline 7 & P.025 & Anggun Prasasti & 0.2750 & 0.0333 & 0.0800 & 0.3883 \\
\hline 8 & P.326 & Anissa Ayu Puspita & 0.1000 & 0.0333 & 0.2000 & 0.3333 \\
\hline 9 & L.190 & Arif Indarmawan & 0.5000 & 0.0296 & 0.2000 & 0.7296 \\
\hline 10 & P.337 & Ariska Harnowo Putri & 0.3000 & 0.0481 & 0.2000 & 0.5481 \\
\hline 11 & L.060 & Arvian Rendy P & 0.2250 & 0.3000 & 0.1200 & 0.6450 \\
\hline 12 & L.176 & Aryarestra Ravida A R & 0.1500 & 0.0444 & 0.1200 & 0.3144 \\
\hline 13 & P.185 & Atik Iis Oktaviasari & 0.1250 & 0.0407 & 0.1200 & 0.2857 \\
\hline 14 & L.174 & Axel Gandy A & 0.1500 & 0.0370 & 0.2000 & 0.3870 \\
\hline 15 & P.176 & Ayu Fitria Nurjanah & 0.5000 & 0.0296 & 0.0800 & 0.6096 \\
\hline 16 & P.203 & Cornelia Ayu Hafsari & 0.0100 & 0.3000 & 0.0800 & 0.3900 \\
\hline 17 & L.181 & Daffa Nur Rafie Alam & 0.2750 & 0.0741 & 0.1200 & 0.4691 \\
\hline 18 & L.145 & Daffa Putra Nugraha & 0.2750 & 0.0481 & 0.2000 & 0.5231 \\
\hline 19 & L.080 & Daffa Rahardian & 0.3000 & 0.0296 & 0.2000 & 0.5296 \\
\hline 20 & L.005 & David Septianus A & 0.3000 & 0.0407 & 0.2000 & 0.5407 \\
\hline 21 & P.207 & Dearista Rahmadhani & 0.1750 & 0.0407 & 0.2000 & 0.4157 \\
\hline 22 & P.063 & Dewanti Wahyu P & 0.2500 & 0.0370 & 0.1200 & 0.4070 \\
\hline 23 & L.089 & Dhimas Haryo Yudho & 0.2750 & 0.3000 & 0.1200 & 0.6950 \\
\hline 24 & L.027 & Dicky Kurniawan & 0.3250 & 0.3000 & 0.2000 & 0.8250 \\
\hline 25 & P.118 & Dina Agustin & 0.1500 & 0.0259 & 0.0800 & 0.2559 \\
\hline 26 & P.035 & Diyah Ayu Pebrianti & 0.2500 & 0.0741 & 0.2000 & 0.5241 \\
\hline 27 & P.204 & Evita Damayanti P & 0.1250 & 0.0333 & 0.2000 & 0.3583 \\
\hline 28 & L.189 & Farkhan Surya Adi K & 0.2750 & 0.0296 & 0.2000 & 0.5046 \\
\hline 29 & P.123 & Fernanda Febrina $\mathrm{S}$ & 0.2750 & 0.3000 & 0.0800 & 0.6550 \\
\hline 30 & L.031 & Gallang Satria M & 0.4500 & 0.3000 & 0.1200 & 0.8700 \\
\hline 31 & P.208 & Gospel E & 0.0150 & 0.0333 & 0.2000 & 0.2483 \\
\hline 32 & P.106 & Hanifah Febriyanti & 0.2750 & 0.0296 & 0.2000 & 0.5046 \\
\hline 33 & P.028 & Hesfa Putri January & 0.3000 & 0.0407 & 0.2000 & 0.5407 \\
\hline 34 & P.006 & Intan Fadhila & 0.2500 & 0.0333 & 0.2000 & 0.4833 \\
\hline 35 & P.179 & Julita Nur Cholifah & 0.0150 & 0.0667 & 0.1200 & 0.2017 \\
\hline 36 & P.047 & Karista Yonika Putri & 0.2500 & 0.0370 & 0.2000 & 0.4870 \\
\hline 37 & L.034 & Kurnia Maulana P & 0.2250 & 0.0667 & 0.1200 & 0.4117 \\
\hline 38 & L.153 & Mahendra Yudha P & 0.2750 & 0.0481 & 0.2000 & 0.5231 \\
\hline 39 & P.327 & Marshella Sari N P & 0.2500 & 0.0370 & 0.2000 & 0.4870 \\
\hline 40 & P.261 & Melladhiva Juand Juliara & 0.2750 & 0.0259 & 0.2000 & 0.5009 \\
\hline
\end{tabular}




\begin{tabular}{|c|c|c|c|c|c|c|}
\hline NO & $\begin{array}{c}\text { NO } \\
\text { PENDAFT. }\end{array}$ & NAMA SISWA BARU & $\begin{array}{c}\text { JUMLAH } \\
\text { NILAI }\end{array}$ & PSIKOTES & PILIHAN & 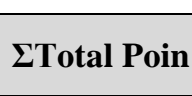 \\
\hline 41 & L.055 & Muhammad Alfian W & 0.0200 & 0.3000 & 0.1200 & 0.4400 \\
\hline 42 & L.061 & Muhammad Y M & 0.1750 & 0.0407 & 0.2000 & 0.4157 \\
\hline 43 & P.019 & Nanda Apriliasari & 0.2750 & 0.0333 & 0.1200 & 0.4283 \\
\hline 44 & P.151 & Nandila Astika N & 0.1000 & 0.0296 & 0.0800 & 0.2096 \\
\hline 45 & P.360 & Nua Lani Anggraini & 0.0200 & 0.0444 & 0.0800 & 0.1444 \\
\hline 46 & P.161 & Pramita Widyadari & 0.0500 & 0.0370 & 0.2000 & 0.2870 \\
\hline 47 & P.291 & R0ssita K & 0.2250 & 0.0444 & 0.2000 & 0.4694 \\
\hline 48 & L.046 & Rakyan Yogaswara & 0.1000 & 0.0333 & 0.2000 & 0.3333 \\
\hline 49 & P.065 & Ratry Yogi R & 0.1500 & 0.0370 & 0.1200 & 0.3070 \\
\hline 50 & L.162 & Rivaldo Pranandito & 0.1250 & 0.0333 & 0.2000 & 0.3583 \\
\hline 51 & P.103 & Rizki Ramadhani & 0.2750 & 0.0444 & 0.1200 & 0.4394 \\
\hline 52 & L.057 & Saptian Azel Adyuta U & 0.2500 & 0.0296 & 0.1200 & 0.3996 \\
\hline 53 & P.256 & Sulfita Aurora Zahra & 0.3250 & 0.0296 & 0.2000 & 0.5546 \\
\hline 54 & P.037 & Wahyu Pramesti & 0.0150 & 0.0407 & 0.1200 & 0.1757 \\
\hline 55 & L.198 & Wali Mahendra Gandhi & 0.4500 & 0.0407 & 0.1200 & 0.6107 \\
\hline 56 & P.352 & Widyani Sekar R & 0.0750 & 0.0333 & 0.0800 & 0.1883 \\
\hline 57 & P.336 & Yohana Yasinta $\mathrm{S}$ & 0.2000 & 0.0333 & 0.2000 & 0.4333 \\
\hline 58 & P.091 & Yolanda Diva R & 0.0150 & 0.0333 & 0.1200 & 0.1683 \\
\hline 59 & L.196 & Yosafat Putra P & 0.0750 & 0.0333 & 0.2000 & 0.3083 \\
\hline 60 & P.104 & Zahra Oktavia S & 0.1750 & 0.0444 & 0.2000 & 0.4194 \\
\hline
\end{tabular}

\section{f. Perangkingan dan Penjurusan}

Langkah terakhir dari metode perhitungan SAW adalah melakukan Perangkingan pada sampel data sebanyak 60 siswa. Adapun hasil dari perangkingannya akan langsung dijuruskan ke masing-masing Mata Pelajaran dan hasilnya disajikan pada Tabel 9.

Tabel 9. Perangkingan dan Penjurusan

\begin{tabular}{|c|c|l|c|c|}
\hline NO & NO PENDAFT. & NAMA SISWA BARU & Total Poin & Jurusan \\
\hline 1 & L.031 & Gallang Satria Mujito & 0.87000 & IPA \\
\hline 2 & L.027 & Dicky Kurniawan & 0.82500 & IPA \\
\hline 3 & L.190 & Arif Indarmawan & 0.72963 & IPA \\
\hline 4 & L.089 & Dhimas Haryo Yudho & 0.69500 & IPA \\
\hline 5 & P.123 & Fernanda Febrina Shenny & 0.65500 & IPA \\
\hline 6 & L.060 & Arvian Rendy Pernanda & 0.64500 & IPA \\
\hline 7 & L.198 & Wali Mahendra Gandhi & 0.61074 & IPA \\
\hline 8 & P.176 & Ayu Fitria Nurjanah & 0.60963 & IPA \\
\hline 9 & P.256 & Sulfita Aurora Zahra & 0.55463 & IPA \\
\hline 10 & P.337 & Ariska Harnowo Putri & 0.54815 & IPA \\
\hline 11 & L.005 & David Septianus Agustia & 0.54074 & IPA \\
\hline 12 & P.028 & Hesfa Putri January & 0.54074 & IPA \\
\hline 13 & P.083 & Agustina Hastini & 0.53333 & IPA \\
\hline 14 & L.080 & Daffa Rahardian & 0.52963 & IPA \\
\hline 15 & P.035 & Diyah Ayu Pebrianti & 0.52407 & IPA \\
\hline 16 & L.145 & Daffa Putra Nugraha & 0.52315 & IPA \\
\hline 17 & L.153 & Mahendra Yudha Pradana & 0.52315 & IPA \\
\hline 18 & L.189 & Farkhan Surya Adi Kirana & 0.50463 & IPA \\
\hline 19 & P.106 & Hanifah Febriyanti & 0.50463 & IPA \\
\hline 20 & P.261 & Melladhiva Juand Juliara & 0.50093 & IPA \\
\hline 21 & P.047 & Karista Yonika Putri & 0.48704 & IPS \\
\hline 22 & P.327 & Marshella Sari Novita Putri & 0.48704 & IPS \\
\hline 23 & P.006 & Intan Fadhila & 0.48333 & IPS \\
\hline 24 & P.291 & R0ssita Kusumaningrum & 0.46944 & IPS \\
\hline 25 & L.181 & Daffa Nur Rafie Alam & 0.46907 & IPS \\
\hline
\end{tabular}




\begin{tabular}{|c|c|c|c|c|}
\hline NO & NO PENDAFT. & NAMA SISWA BARU & Total Poin & Jurusan \\
\hline 26 & L.055 & Muhammad Alfian Wibisono & 0.44000 & IPS \\
\hline 27 & P.103 & Rizki Ramadhani & 0.43944 & IPS \\
\hline 28 & P.336 & Yohana Yasinta Sidabutar & 0.43333 & IPS \\
\hline 29 & P.019 & Nanda Apriliasari & 0.42833 & IPS \\
\hline 30 & P.104 & Zahra Oktavia Syahrani & 0.41944 & IPS \\
\hline 31 & P.207 & Dearista Rahmadhani & 0.41574 & IPS \\
\hline 32 & L.061 & Muhammad Yusyfarijal Marufi & 0.41574 & IPS \\
\hline 33 & L.034 & Kurnia Maulana Putra & 0.41167 & IPS \\
\hline 34 & P.063 & Dewanti Wahyu Purwaningsih & 0.40704 & IPS \\
\hline 35 & L.057 & Saptian Azel Adyuta Utama & 0.39963 & IPS \\
\hline 36 & P.203 & Cornelia Ayu Hafsari & 0.39000 & IPS \\
\hline 37 & P.025 & Anggun Prasasti & 0.38833 & IPS \\
\hline 38 & L.174 & Axel Gandy Arthayuda & 0.38704 & IPS \\
\hline 39 & P.204 & Evita Damayanti Puteri & 0.35833 & IPS \\
\hline 40 & L.162 & Rivaldo Pranandito & 0.35833 & IPS \\
\hline 41 & L.009 & Andreas Ani Asmara & 0.35593 & BAHASA \\
\hline 42 & P.326 & Anissa Ayu Puspita & 0.33333 & BAHASA \\
\hline 43 & L.046 & Rakyan Yogaswara & 0.33333 & BAHASA \\
\hline 44 & P.005 & Anggita Yuniarti & 0.31722 & BAHASA \\
\hline 45 & L.176 & Aryarestra Ravida A R & 0.31444 & BAHASA \\
\hline 46 & L.196 & Yosafat Putra Pamungkas & 0.30833 & BAHASA \\
\hline 47 & P.065 & Ratry Yogi Rahmawati & 0.30704 & BAHASA \\
\hline 48 & P.161 & Pramita Widyadari & 0.28704 & BAHASA \\
\hline 49 & P.185 & Atik Iis Oktaviasari & 0.28574 & BAHASA \\
\hline 50 & P.134 & Anggita Ayu Kurniasih & 0.27833 & BAHASA \\
\hline 51 & P.038 & Alicia Syafa Azizah & 0.26352 & BAHASA \\
\hline 52 & P.118 & Dina Agustin & 0.25593 & BAHASA \\
\hline 53 & P.208 & Gospel Enggaringtyas & 0.24833 & BAHASA \\
\hline 54 & P.151 & Nandila Astika Ningrum & 0.20963 & BAHASA \\
\hline 55 & P.179 & Julita Nur Cholifah & 0.20167 & BAHASA \\
\hline 56 & P.352 & Widyani Sekar Ramadhania & 0.18833 & BAHASA \\
\hline 57 & P.037 & Wahyu Pramesti & 0.17574 & BAHASA \\
\hline 58 & P.091 & Yolanda Diva Rusdyana & 0.16833 & BAHASA \\
\hline 59 & P.167 & Agustira Fatima Azzahra & 0.15963 & BAHASA \\
\hline 60 & P.360 & Nua Lani Anggraini & 0.14444 & BAHASA \\
\hline
\end{tabular}

\section{Perancangan Sistem}

Dalam bagian ini disajikan use case diagram dan class diagram dari sistem yang diusulkan.

\section{a. Use Case}

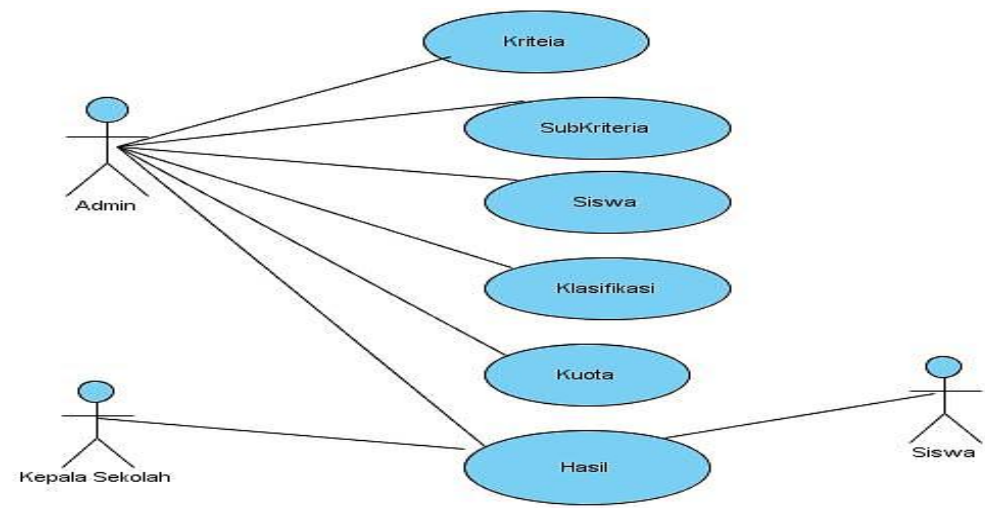

Gambar 1. Use Case Sistem

Pada perancangan sistem tersebut terdapat beberapa pengguna yaitu Admin, Kepala Sekolah dan Siswa. Setiap pengguna mempunyai fitur yang berbeda-beda. Admin 
mempunyai fitur untuk melakukan pengelolaan data kriteria, sub kriteria, data siswa, klasifikasi dan melihat hasil. Pengguna level kepala sekolah dan siswa mempunyai fitur melihat hasil dari sistem penjurusan yang telah diproses oleh aplikasi.

\section{b. Class Diagram}

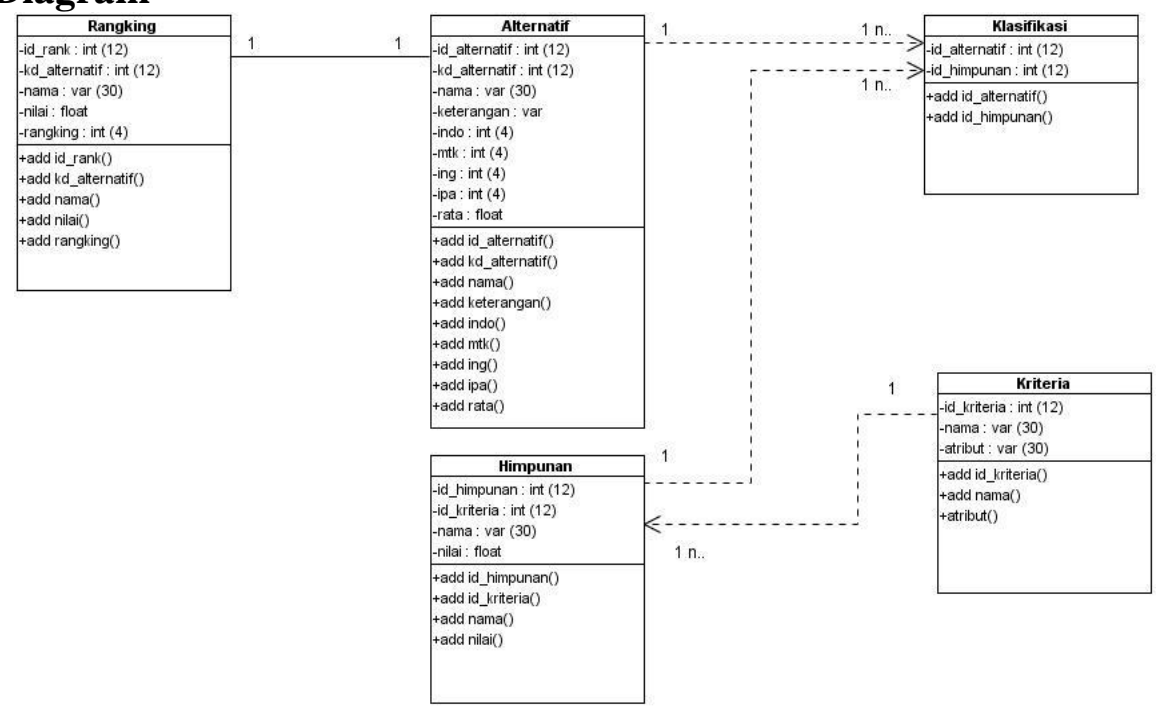

Gambar 2. Class Diagram

Class diagram adalah diagram yangmenggambarkan struktur sistem dari segi pendefinisian kelas-kelas yang akan dibuat untuk membangun sistem. Class memiliki 3 bagian utama yaitu attribute, operation, dan name. Class yang ada pada sistem harus dapat melakukan fungsinya sesuai dengan kebutuhan sistem.

\subsection{Implementasi Sistem}

\section{a. Form Analisa Data $S A W$}

Pada halaman ini sistem akan menampilkan form analisa pembobotan yang nantinya setiap kriteria akan diberi nilai bobot yang berbeda-beda.

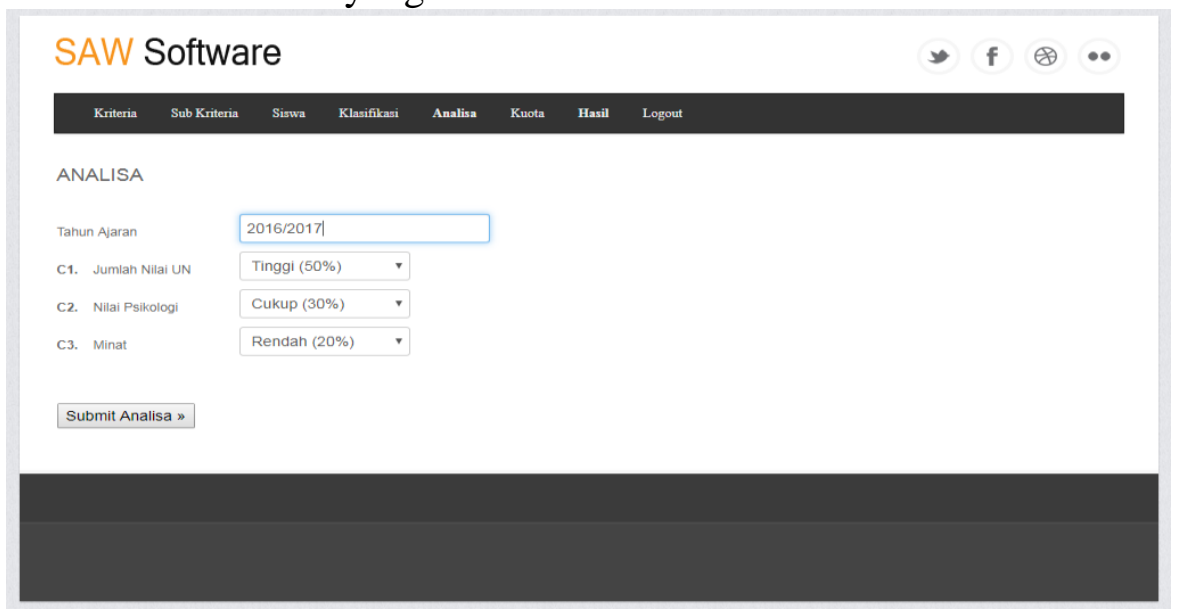

Gambar 3. Form Analisa Data SAW

\section{c. Halaman Hasil Penjurusan}

Halaman konsultasi merupakan halaman yang digunakan oleh pengguna untuk menampilkan hasil perhitungan atau pemrosesan dengan metode $S A W$. 


\section{SAW Software $\quad$ f $\&$ \\ Kriteria Sub Rriteria Sisme Klasifflasi Amalisa Kuota Hasil Logout}

Hasil Alternatif Penjurusan Periode Tahun Ajaran 2016/2017

\begin{tabular}{|c|c|c|c|c|c|}
\hline No & No Pendaftaran & Nama Siswa & Nilas & Jurusan & Trhun Ajaran \\
\hline 1 & L.031 & GALLANG SATRIA MUIITO & 0.87 & IPA & 20162017 \\
\hline 2 & L. 027 & DICKY KURNIAWAN & 0.825 & IPA & 20162017 \\
\hline 3 & L. 190 & ARIF INDARMAWAN & 0.7297 & IPA & $2016 / 2017$ \\
\hline 4 & L.089 & DHINAAS HARYO YUDHO & 0.695 & IPA & 20162017 \\
\hline 5 & P.123 & FERNANDA FEBRNA SHENNY & 0.655 & IPA & $2016 / 2017$ \\
\hline 6 & L.060 & ARVLAN RENDY PERNANDA & 0.645 & IPA & 20162017 \\
\hline 7 & L. 198 & WALI MAHENDRA GANDHI & 0.6108 & IPA & 20162017 \\
\hline 8 & p.176 & AYU FIIRIA NURJANAH & 0.6097 & IPA & 20162017 \\
\hline 9 & P 256 & SULFITA AURORA ZAHRA & 0.5547 & IPA & 20162017 \\
\hline 10 & P 337 & ARISKA HARNOWO PUIRI & 0.548 & IPA & 20162017 \\
\hline 11 & p 028 & HESFA PUTRI JANUARY & 0.5408 & IPA & 20162017 \\
\hline 12 & L.005 & DAVID SEPTIANUS AGUSTIA & 0.5408 & $\mathbb{P A} A$ & 20162017 \\
\hline 13 & p.083 & AGUSTINA HASTINI & 0.5333 & IPA & 2016/2017 \\
\hline 14 & L.080 & DAFFA RAHARDIAN & 0.5297 & IPA & 20162017 \\
\hline 15 & p.035 & DIYAH AYU PEBRIANTI & 0.5241 & IPA & $2016 / 2017$ \\
\hline 16 & L. 153 & NCAHENDRA YUDHA PRADANA & 0.523 & IPA & 20162017 \\
\hline 17 & L. 145 & DAFFA PUTRA NUGRAHA & 0.523 & IPA & 20162017 \\
\hline 18 & L. 189 & FARKHAN SURYA ADI KIRANA & 0.5047 & $\mathrm{PPA}$ & 20162017 \\
\hline 19 & P.106 & HANIFAH FEBRIYANTI & 0.5047 & $\mathrm{PPA}$ & $2016 / 2017$ \\
\hline 20 & P261 & MELLADHIVA JUAND JLLARA & 0.5008 & IPA & 20162017 \\
\hline 21 & $\mathrm{P} 047$ & KARISTA YONTKA PUTRI & 0.4869 & IPS & 20162017 \\
\hline 22 & p 327 & MAARSHELLA SARI NOVITA PUTRI & 0.4869 & IPS & 20162017 \\
\hline 23 & P.006 & INTAN FADHILAA & 0.4833 & IPS & $2016 / 2017$ \\
\hline 24 & P291 & ROSSITA KUSUMANINGRUM & 0.4694 & IPS & $2016 / 2017$ \\
\hline 25 & L. 181 & DAFFA NUR RAFIE ALAMS & 0.4691 & IPS & 2016/2017 \\
\hline 26 & L.055 & MUHAMMAD ALFIAN WIBISONO & 0.44 & IPS & 20162017 \\
\hline 27 & P.103 & RIZKI RAMAADHANI & 0.4394 & IPS & 2016/2017 \\
\hline 28 & P 336 & YOHANA YASINTA SIDABUTAR & 0.4333 & IPS & 20162017 \\
\hline 29 & P.019 & NANDA APRIIIASARI & 0.4283 & IPS & $2016 / 2017$ \\
\hline 30 & P.104 & ZAHRA OKTAVIA SYAHRANT & 0.4194 & IPS & 20162017 \\
\hline
\end{tabular}

Gambar 4 Halaman Hasil Penjurusan

\subsection{PENGUJIAN APLIKASI}

Pengujian Aplikasi merupakan suatu langkah atau metode yang dilakukan untuk studi kelayakan dari sebuah sistem yang dibangun dalam suatu penelitian. Adapun pengujian sistem ini menggunakan metode Blackbox, adapun kesimpulan dari pengujian tersebut ditunjukkan pada Tabel 10.

Tabel 10. Pengujian Blackbox

\begin{tabular}{|c|c|c|c|c|}
\hline No & $\begin{array}{l}\text { Skenario } \\
\text { Pengujian }\end{array}$ & Hasil Yang Diharapkan & Hasil Pengujian & $\begin{array}{l}\text { Kesimpu } \\
\text {-lan }\end{array}$ \\
\hline 1 & $\begin{array}{l}\text { Memasukan } \\
\text { Username }\end{array}$ & $\begin{array}{l}\text { Sistem dapat menginputkan data } \\
\text { username }\end{array}$ & $\begin{array}{l}\text { Sistem dapat mengimputkan } \\
\text { username pengguna }\end{array}$ & Valid \\
\hline 2 & $\begin{array}{l}\text { Memasukan } \\
\text { Password }\end{array}$ & $\begin{array}{l}\text { Sistem dapat menginputkan data } \\
\text { password }\end{array}$ & $\begin{array}{l}\text { Sistem dapat mengimputkan } \\
\text { password pengguna }\end{array}$ & Valid \\
\hline 3 & Verifikasi & $\begin{array}{l}\text { Sistem dapat harus dapat } \\
\text { melakukan verifikasi akun } \\
\text { pengguna }\end{array}$ & $\begin{array}{l}\text { Sistem dapat melakukan } \\
\text { verifikasi pengguna }\end{array}$ & Valid \\
\hline 4 & Notifikasi & $\begin{array}{l}\text { Sistem harus dapat } \\
\text { memmberikan notifikasi secara } \\
\text { responsif }\end{array}$ & $\begin{array}{l}\text { Sistem Tidak bisa memberikan } \\
\text { notifikasi kesalahan }\end{array}$ & $\begin{array}{l}\text { Tidak } \\
\text { Valid }\end{array}$ \\
\hline 5 & $\begin{array}{l}\text { Memasukan } \\
\text { data kriteria }\end{array}$ & $\begin{array}{l}\text { Sistem dapat melakukan input } \\
\text { data kriteria }\end{array}$ & $\begin{array}{l}\text { Sistem dapat memasukan data } \\
\text { kriteria }\end{array}$ & Valid \\
\hline 6 & $\begin{array}{l}\text { Melakukan } \\
\text { edit kriteria }\end{array}$ & $\begin{array}{l}\text { Sistem dapat melakukan edit } \\
\text { data kriteria }\end{array}$ & $\begin{array}{l}\text { Sistem dapat melakukan edit } \\
\text { data kriteria }\end{array}$ & Valid \\
\hline 7 & $\begin{array}{l}\text { Melakukan } \\
\text { hapus data } \\
\text { kriteria }\end{array}$ & $\begin{array}{l}\text { Sistem dapat melakukan hapus } \\
\text { data kriteria }\end{array}$ & $\begin{array}{l}\text { Sistem dapat melakukan hapus } \\
\text { data kriteria }\end{array}$ & Valid \\
\hline 8 & $\begin{array}{l}\text { Melakukan } \\
\text { validasi data } \\
\text { kriteria }\end{array}$ & $\begin{array}{l}\text { Sistem dapat melakukan } \\
\text { validasi data kriteria }\end{array}$ & $\begin{array}{l}\text { Sistem Tidak bisa Melakukan } \\
\text { validasi data kriteria }\end{array}$ & $\begin{array}{l}\text { Tidak } \\
\text { Valid }\end{array}$ \\
\hline
\end{tabular}




\begin{tabular}{|c|c|c|c|c|}
\hline No & $\begin{array}{l}\text { Skenario } \\
\text { Pengujian }\end{array}$ & Hasil Yang Diharapkan & Hasil Pengujian & $\begin{array}{l}\text { Kesimpu } \\
\text {-lan }\end{array}$ \\
\hline 9 & $\begin{array}{l}\text { Memasukan } \\
\text { data sub } \\
\text { kriteria }\end{array}$ & $\begin{array}{l}\text { Sistem dapat melakukan input } \\
\text { data sub kriteria }\end{array}$ & $\begin{array}{l}\text { Sistem dapat memasukan data } \\
\text { sub kriteria }\end{array}$ & Valid \\
\hline 10 & $\begin{array}{l}\text { Melakukan } \\
\text { edit sub } \\
\text { kriteria }\end{array}$ & $\begin{array}{l}\text { Sistem dapat melakukan edit } \\
\text { data sub kriteria }\end{array}$ & $\begin{array}{l}\text { Sistem dapat melakukan edit } \\
\text { data sub kriteria }\end{array}$ & Valid \\
\hline 11 & $\begin{array}{l}\text { Melakukan } \\
\text { hapus data } \\
\text { sub kriteria }\end{array}$ & $\begin{array}{l}\text { Sistem dapat melakukan hapus } \\
\text { data sub kriteria }\end{array}$ & $\begin{array}{l}\text { Sistem dapat melakukan hapus } \\
\text { data sub kriteria }\end{array}$ & Valid \\
\hline 12 & $\begin{array}{l}\text { Melakukan } \\
\text { validasi data } \\
\text { sub kriteria }\end{array}$ & $\begin{array}{l}\text { Sistem dapat melakukan } \\
\text { validasi data sub kriteria }\end{array}$ & $\begin{array}{l}\text { Sistem Tidak bisa Melakukan } \\
\text { validasi data sub kriteria }\end{array}$ & $\begin{array}{l}\text { Tidak } \\
\text { Valid }\end{array}$ \\
\hline 13 & $\begin{array}{l}\text { Memasukan } \\
\text { data sub } \\
\text { alternatif }\end{array}$ & $\begin{array}{l}\text { Sistem dapat melakukan input } \\
\text { data sub alternatif }\end{array}$ & $\begin{array}{l}\text { Sistem dapat memasukan data } \\
\text { sub alternatif }\end{array}$ & Valid \\
\hline 14 & $\begin{array}{l}\text { Melakukan } \\
\text { edit sub } \\
\text { alternatif }\end{array}$ & $\begin{array}{l}\text { Sistem dapat melakukan edit } \\
\text { data sub alternatif }\end{array}$ & $\begin{array}{l}\text { Sistem dapat melakukan edit } \\
\text { data sub alternatif }\end{array}$ & Valid \\
\hline 15 & $\begin{array}{l}\text { Melakukan } \\
\text { hapus data } \\
\text { sub alternatif }\end{array}$ & $\begin{array}{l}\text { Sistem dapat melakukan hapus } \\
\text { data sub alternatif }\end{array}$ & $\begin{array}{l}\text { Sistem dapat melakukan hapus } \\
\text { data sub alternatif }\end{array}$ & Valid \\
\hline 16 & $\begin{array}{l}\text { Melakukan } \\
\text { validasi data } \\
\text { sub alternatif }\end{array}$ & $\begin{array}{l}\text { Sistem dapat melakukan } \\
\text { validasi data sub alternatif }\end{array}$ & $\begin{array}{l}\text { Sistem dapat Melakukan } \\
\text { validasi data sub alternatif }\end{array}$ & Valid \\
\hline 17 & $\begin{array}{l}\text { Melakukan } \\
\text { pengelompo } \\
\text { kan data }\end{array}$ & $\begin{array}{l}\text { Sistem dapat melakukan } \\
\text { pengelompokan atau pengisian } \\
\text { data kriteria pada setiap } \\
\text { alternatif }\end{array}$ & $\begin{array}{l}\text { Sistem dapat melakukan } \\
\text { pengelompokan atau pengisian } \\
\text { data kriteria pada setiap } \\
\text { alternatif }\end{array}$ & Valid \\
\hline 18 & $\begin{array}{l}\text { Cek Validasi } \\
\text { data }\end{array}$ & $\begin{array}{l}\text { Sistem dapat melakukan } \\
\text { pengecekan data yang rangkap } \\
\text { dan valid }\end{array}$ & $\begin{array}{l}\text { Sistem dapat melakukan } \\
\text { pengecekan data yang rangkap } \\
\text { dan valid }\end{array}$ & Valid \\
\hline 19 & $\begin{array}{l}\text { Pembobotan } \\
\text { kriteria }\end{array}$ & $\begin{array}{l}\text { Sistem dapat melakukan } \\
\text { pembobotan kriteria }\end{array}$ & $\begin{array}{l}\text { Sistem dapat melakukan } \\
\text { pembobotan kriteria }\end{array}$ & Valid \\
\hline 20 & $\begin{array}{l}\text { Perhitungan } \\
\text { menggunaka } \\
\text { n SAW }\end{array}$ & $\begin{array}{l}\text { Sistem dapat melakukan proses } \\
\text { perhitungan dengan Metode } \\
\text { SAW }\end{array}$ & $\begin{array}{l}\text { Sistem dapat melakukan proses } \\
\text { perhitungan dengan Metode } \\
\text { SAW }\end{array}$ & Valid \\
\hline 21 & $\begin{array}{l}\text { Menampilka } \\
\text { n hasil } \\
\text { seleksi }\end{array}$ & $\begin{array}{l}\text { Sistem dapat menampilkan hasil } \\
\text { seleksi }\end{array}$ & $\begin{array}{l}\text { Sistem dapat menampilkan hasil } \\
\text { seleksi }\end{array}$ & Valid \\
\hline 22 & $\begin{array}{l}\text { Melakukan } \\
\text { perangkinga } \\
\mathrm{n}\end{array}$ & $\begin{array}{l}\text { Sistem dapat melakukan } \\
\text { perangkingan berdasarkan nilai } \\
\text { poin yang paling besar }\end{array}$ & $\begin{array}{l}\text { Sistem dapat melakukan } \\
\text { perangkingan berdasarkan nilai } \\
\text { poin yang paling besar }\end{array}$ & Valid \\
\hline 23 & $\begin{array}{l}\text { Hasil } \\
\text { perhitungan }\end{array}$ & $\begin{array}{l}\text { Hasil perhitungan sama dengan } \\
\text { pehitungan manual }\end{array}$ & $\begin{array}{l}\text { Hasil perhitungan sama dengan } \\
\text { pehitungan manual }\end{array}$ & Valid \\
\hline 24 & Reporting & $\begin{array}{l}\text { Sistem dapat melakukan export } \\
\text { data kedalam file tertentu }\end{array}$ & $\begin{array}{l}\text { Sistem tidak dapat melakukan } \\
\text { export data kedalam file tertentu }\end{array}$ & $\begin{array}{l}\text { Tidak } \\
\text { Valid }\end{array}$ \\
\hline 25 & $\begin{array}{l}\text { Hasil dapat } \\
\text { dilihat oleh } \\
\text { pemilik }\end{array}$ & $\begin{array}{l}\text { Hasil seleksi dapat diakses oleh } \\
\text { pemilik sistem informasi }\end{array}$ & $\begin{array}{l}\text { Hasil seleksi dapat diakses oleh } \\
\text { pemilik sistem informasi }\end{array}$ & Valid \\
\hline
\end{tabular}

Perhitungan nilai kinerja sistem yang dibangun oleh Peneliti dengan rumus sebagai berikut:

Nilai Kelayakan Sistem $=($ Jumlah Valid $/$ ¿Skenario Pengujian $) \times 100$ 
Berdasarkan rumus di atas maka nilai kelayakan sistem adalah sebagai berikut:

Nilai Kelayakan Sistem $=(21 / 25) \times 100=84$

Sehingga hasil pengujian kelayakan sistem, dengan skenario pengujian sebanyak 25 butir uji, 21 valid dan 4 tidak valid. Maka nilai kelayakan sistem tersebut sebesar $84 \%$, dengan demikian aplikasi tersebut layak di gunakan, meskipun perbaikan dan penyempurnaan masih perlu dilakukan.

\section{PENUTUP}

\subsection{Kesimpulan}

Berdasarkan penelitian yang dilakukan, dapat diperoleh simpulan sebagai berikut:

1. Sistem Pendukung Keputusan Penjurusan Siswa sesuai dengan metode Simple Additive Weighted (SAW).

2. Pengujian Sistem Pendukung Keputusan, dengan skenario pengujian sebanyak 25 butir uji, nilai valid 21 dan nilai tidak valid 4. Maka nilai kelayakan sistem sebesar 84 $\%$, maka aplikasi ini layak digunakan.

3. Hasil perhitungan Simple Additive Weighted dapat menjadi alternatif pilihan dalam menentukan penjurusan siswa di sekolah tersebut.

\subsection{Saran}

1. Sistem yang dibangun oleh Peneliti perlu dikembangkan lagi dengan metode pendukung keputusan yang berbeda.

2. Hasil dari Sistem Pendukung Keputusan Penjurusan Siswa ini, sebaiknya sebagai alternatif dalam mengambil keputusan.

\section{DAFTAR PUSTAKA}

Jaberidoost, M., Olfat, L., Hosseini, A., Kebriaeezadeh, A., Abdollahi, M., Alaeddini, M., \& Dinarvand, R. (2015). Pharmaceutical Supply Chain Risk Assessment In Iran Using Analytic Hierarchy Process (Ahp) And Simple Additive Weighting (Saw) Methods. Journal Of Pharmaceutical Policy And Practice, 8(1), 1-10. Https://Doi.Org/10.1186/S40545-015-0029-3

Kusrini. (2010). Konsep Dan Aplikasi Sistem Pendukung Keputusan. Yogyakarta.

Kustiyahningsih, Y., \& Rahmanita, E. (2016). Aplikasi Sistem Pendukung Keputusan Menggunakan Algoritma C4.5. Untuk Penjurusan Sma. Jurnal Semantec, 5(2), 101108.

Nugroho, Y. S., \& Haryati, S. N. (2015). Klasifikasi Dan Klastering Penjurusan Siswa Sma Negeri 3 Boyolali. Khazanah Informatika, 1(1), 1-6.

Sasongko, N. T., Tomo, S., \& Fitriasih, S. H. (2018). Sistem Penunjang Keputusan Calon Desa Penerima Air Bersih Di Kecamatan Sumberlawang Sragen Menggunakan. Jurnal TIKomSiN, 6(1), 37-44.

Shakouri G., H., Nabaee, M., \& Aliakbarisani, S. (2014). A quantitative discussion on the assessment of power supply technologies: DEA (data envelopment analysis) and SAW (simple additive weighting) as complementary methods for the "Grammar." Energy, 64, 640-647. https://doi.org/10.1016/J.ENERGY.2013.10.022

Tamošaitienè, J., Zavadskas, E. K., \& Turskis, Z. (2013). Multi-criteria Risk Assessment of a Construction Project. Procedia Computer Science, 17, 129-133. https://doi.org/10.1016/J.PROCS.2013.05.018

$\mathrm{Yu}, \mathrm{J}$. W. (2015). A fuzzy multi-criteria decision-making model based on simple additive weighting method and relative preference relation. Appl. Soft Comput., 30, 412-420. 